\title{
Mono- to Octachlorinated Polychlorinated Dibenzo-p-dioxin and Dibenzofuran Emissions from Sintering Plants Synergistically Controlled by the Desulfurization Process
}

Mengjing Wang, ${ }^{\dagger, \ddagger}$ Wenbin Liu, $^{*}, \dagger, \ddagger$ Meifang Hou, ${ }^{\S}$ Qianqian Li, ${ }^{\dagger, \ddagger}$ Ying Han, ${ }^{\dagger, \ddagger}$ Haifeng Li, ${ }^{\dagger, \ddagger}$ Nan Yan, ${ }^{\dagger, \dagger}$ and Minghui Zheng ${ }^{\dagger, \ddagger}$

${ }^{\dagger}$ State Key Laboratory of Environmental Chemistry and Ecotoxicology, Research Center for Eco-Environmental Sciences, Chinese Academy of Sciences, Beijing 100085, China

${ }^{\ddagger}$ University of Chinese Academy of Sciences, Beijing 100049, China

${ }^{\S}$ School of Ecological Technology and Engineering, Shanghai Institute of Technology, Shanghai 201418, China

Supporting Information

ABSTRACT: The influence of desulfurization systems in sintering plants on polychlorinated dibenzo-p-dioxin and dibenzofuran $(\mathrm{PCDD} / \mathrm{F})$ concentrations, profiles, and emission factors was studied. Mono- to tri-CDD/Fs and tetra- to octa-CDD/F concentrations were $4.4 \pm 2.3$ and $10.5 \pm 8.3 \mathrm{ng}$ $\mathrm{m}^{-3}$, respectively, at the inlets and $0.87 \pm 0.48$ and $0.47 \pm 0.22$ $\mathrm{ng} \mathrm{m}^{-3}$, respectively, after desulfurization. The toxic equivalents (TEQs) were $0.95 \pm 0.093$ and $0.51 \pm 0.040 \mathrm{ng}$ of I-TEQ $\mathrm{m}^{-3}$ at the inlets and after desulfurization, respectively. The congener profiles and homologue distributions were dominated by $2-\mathrm{MoCDF}$ and MoCDF, respectively. The PCDD/F removal efficiencies achieved by desulfurization increased as the chlorination level increased. The PCDD/Fs became adsorbed to gypsum. Annual mono- to tri-CDD/Fs $\mathrm{PCDD} / \mathrm{F}$ and TEQ (tetra- to octa-CDD/F) emission factors for flue gas and gypsum between 2003 and 2012 were determined. The total amounts of mono- to tri-CDD/Fs emitted in flue gas and gypsum between 2003 and 2012 were 10.7 and $10.2 \mathrm{~kg}$, respectively. The total TEQs emitted in flue gas and gypsum between 2003 and 2012 were estimated to be 15486 and $1878 \mathrm{~g}$ of I-TEQ respectively. PCDD/Fs adsorbed to gypsum are not effectively eliminated. The PCDD/F concentrations increased as the fly ash surface area increased moving through the electrostatic precipitator stages.

\section{INTRODUCTION}

Polychlorinated dibenzo-p-dioxins and polychlorinated dibenzofurans (PCDDs and PCDFs, together called PCDD/Fs) pose risks to the environment and human health around the world because they are toxic and persistent and undergo long-range transport. PCDD/Fs are formed unintentionally during many thermal industrial activities, such as combustion processes and in processes in metallurgical and chemical plants. ${ }^{1-5}$ Identifying potential $\mathrm{PCDD} / \mathrm{F}$ sources is an essential primary step when determining which sources should be prioritized when implementing emission controls. According to the most recent $\mathrm{PCDD} / \mathrm{F}$ emission inventory, the contribution of $\mathrm{PCDD} / \mathrm{F}$ emissions from Chinese sintering plants to the total Chinese industrial $\mathrm{PCDD} / \mathrm{F}$ emissions to the atmosphere increased from $30.2 \%$ in 2003 to $34.8 \%$ in 2012 .

Sintering is an important industry in China. Approximately $40 \%$ of the global iron ore sintering production currently occurs in China. Elaborate gas cleaning measures have been implemented to decrease PCDD/Fs emissions from sintering plants to meet emission legislation. These measures include not

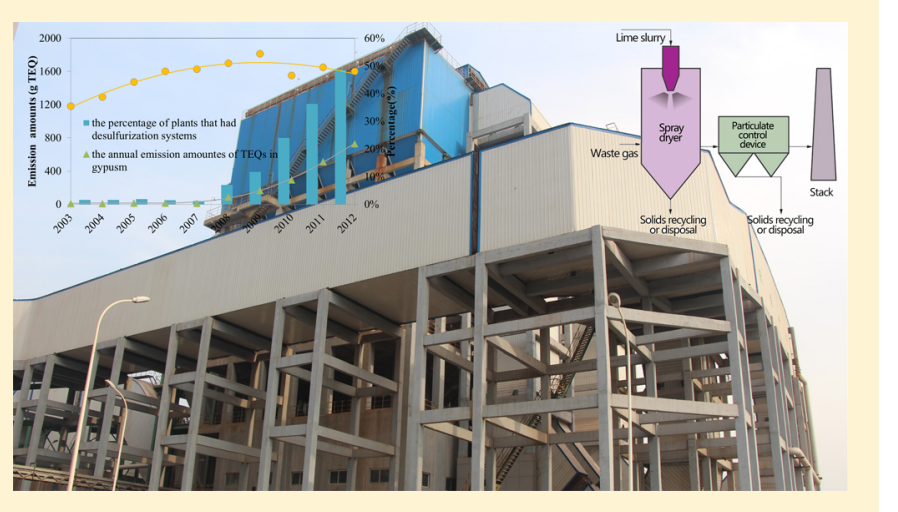


chlorinated PCDD/Fs [the mono (Mo), di (Di), and tri (Tr) chlorodibenzo- $p$-dioxins and chlorodibenzofurans] from sintering plants are available. ${ }^{14,15}$ The formation pathways of less to more chlorinated PCDFs can explain the dominant congeners and explain the distribution of congener profiles and why $2,3,4,7,8-\mathrm{PeCDF}$ is the largest contributor of TEQs in the main organic chemical industries. ${ }^{14} \mathrm{MoCDF}$ to TrCDFs contributed more than $95 \%$ of the total PCDF concentrations in serum samples from the operators of a municipal solid waste incinerator in Korea and people living near the incinerator. ${ }^{16}$ Some MoCDF congeners are mutagenic and embryotoxic. ${ }^{17}$ The less chlorinated PCDD/Fs contribute more than the 2,3,7,8-chlorinated $\mathrm{PCDD} / \mathrm{Fs}$ to the total $\mathrm{PCDD} / \mathrm{F}$ concentrations in the atmosphere. ${ }^{18}$ Therefore, less chlorinated PCDD/Fs could have significant effects on humans and the environment, but these effects have been almost ignored. It is therefore important to identify potential sources of and to characterize emissions of MoCDD/Fs to TrCDD/Fs.

Emissions of $\mathrm{SO}_{2}$ from Chinese sintering plants exceeded $140 \times 10^{6}$ tons (7.3\% of total industrial $\mathrm{SO}_{2}$ emissions) in 2012. Desulfurization systems have recently been introduced to control air pollution by removing $\mathrm{SO}_{2}$ from sintering plant flue gases. Desulfurization systems have been found to remove various pollutants, including dust and $\mathrm{NOx}$, at the same time they remove $\mathrm{SO}_{2} \cdot{ }^{19}$ However, no systematic research into the possibility of synergistically controlling PCDD/Fs emissions in sintering flue gas using desulfurization systems has previously been described.

Four typical sintering plants were used in this study. Flue gas samples were collected at the desulfurization system inlets and outlets to investigate the influences the systems had on the concentrations and profiles of the MoCDD/Fs to octa $(\mathrm{O})$ $\mathrm{CDD} / \mathrm{Fs}$ emitted and used to derive the emission factors. Fly ash and gypsum samples were also collected to improve our understanding of the release of $\mathrm{MoCDD} / \mathrm{F}$ to $\mathrm{OCDD} / \mathrm{F}$ from sintering plants.

\section{MATERIALS AND METHODS}

Sampling. Sintering flue gases are at high temperatures and contain large amounts of particles, so a baghouse cannot be used. An electrostatic precipitator therefore has to be used to decrease the amounts of particles emitted. Electrostatic precipitators significantly increase the amounts of PCDD/Fs that form during the sintering process, but this was ignored.

Sintering plants in China currently most commonly use wet or semidry desulfurization systems, the schematics of which are shown in Figure 1. In a wet desulfurization system, the flue gas is treated with a sorbent slurry in an aqueous medium before
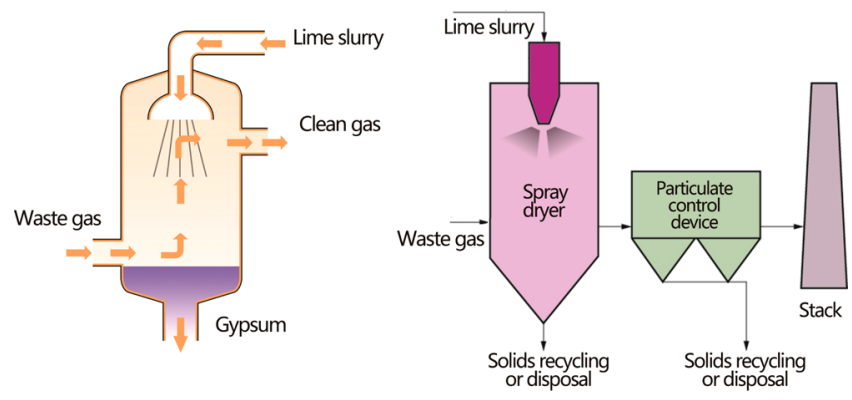

Figure 1. Schematics of a wet desulfurization system (left) and a semidry desulfurization system (right). being emitted to the atmosphere. In a semidry desulfurization system, an aqueous sorbent slurry similar to that used in a wet system but at a higher sorbent concentration is used. The waste products are collected using a standard particulate matter collection device, such as a baghouse.

Four sintering plants, DH, TS, SK, and ST, with sintering areas of $90,180,360$, and $500 \mathrm{~m}^{2}$, respectively, were studied. In China, small sintering plants (area of $<90 \mathrm{~m}^{2}$ ) are mostly equipped with wet desulfurization systems, whereas medium $\left(90-180 \mathrm{~m}^{2}\right)$ and large $\left(>180 \mathrm{~m}^{2}\right)$ plants tend to be equipped with semidry systems. Plant DH had a wet desulfurization system, and plants TS, SK, and ST had semidry systems. Operational information for plants DH, TS, SK, and ST is given in Table S1.

Six flue gas samples were collected from each plant, three at the inlet and three at the outlet. The samples were collected using an automatic isokinetic sampling system (Tecora Corp., Milan, Italy). The sample collection methods have previously been described in detail. ${ }^{14}$ Briefly, the sampling train included a heated probe, a filter box with a quartz-fiber filter, and a watercooled XAD-2 adsorbent trap. The quartz-fiber filter collected particulate-bound pollutants, and the XAD-2 adsorbent resin trapped vapor-phase contaminants. A gypsum sample was collected from the desulfurization system at each plant. Four fly ash samples were collected from different stages of the electrostatic precipitators that were connected in series in plants $\mathrm{DH}$ and TS. One fly ash sample (a mixture of fly ash from all of the stages) was collected from the electrostatic precipitator in SK and ST because it was not practical to collect a sample from each stage of the precipitators.

MoCDD/F to OCDD/F Analysis. The 2,3,7,8-chlorinated PCDD/Fs were analyzed following standard method EN-1948, which has been described previously. ${ }^{20-22}$ Briefly, each sample was spiked with ${ }^{13} \mathrm{C}$-labeled PCDD/F internal standards (EN1948 ES; Cambridge Isotope Laboratories, Andover, MA) and then Soxhlet extracted with $250 \mathrm{~mL}$ of toluene for $\sim 24 \mathrm{~h}$. Before extraction, the fly ash and gypsum samples were treated with $1 \mathrm{M} \mathrm{HCl}$. Each extract was purified by being passed through a multilayer silica gel column and a basic alumina column. The extract was then spiked with ${ }^{13} \mathrm{C}_{12}$-labeled PCDD/Fs (EN-1948 IS; Cambridge Isotope Laboratories) to allow the native PCDD/Fs and labeled internal standards to be quantified.

The MoCDD/Fs to $\operatorname{TrCDD} / \mathrm{Fs}$ in each sample were qualitatively and quantitatively analyzed. A ${ }^{13} \mathrm{C}$-labeled internal standard (EDF-4955; Cambridge Isotope Laboratories) containing 2-MoCDD, 2,3-DiCDD, 2,3,7-TrCDD, 2-MoCDF, 2,8DiCDF, and 2,4,8-TrCDF was added before the sample was extracted, and an aliquot of the extract was concentrated and then passed through a multilayer silica gel column eluted with $100 \mathrm{~mL}$ of hexane. The extract was evaporated and passed through a column containing $8 \mathrm{~g}$ of basic alumina, which was eluted with $80 \mathrm{~mL}$ of $2 \%$ dichloromethane in hexane and then $150 \mathrm{~mL}$ of $12 \%$ dichloromethane in hexane. The second fraction, containing the $\mathrm{MoCDD} / \mathrm{Fs}$ to $\mathrm{TrCDD} / \mathrm{Fs}$, was concentrated to $40 \mu \mathrm{L}$ of nonane under a gentle stream of nitrogen.

The MoCDD/Fs to OCDD/Fs were analyzed using an Agilent 6890 high-resolution gas chromatograph (Agilent Technologies, Santa Clara, CA) coupled to an Autospec Ultima high-resolution mass spectrometer (Waters, Milford, MA). The gas chromatograph was equipped with a DB-5MS column $(60 \mathrm{~m} \times 0.25 \mathrm{~mm} \times 0.25 \mu \mathrm{m}$, Agilent Technologies $)$. 
Table 1. PCDD/F Concentrations in the Samples

\begin{tabular}{|c|c|c|c|c|c|}
\hline & & & MoCDD/Fs to TrCDD/Fs & 2,3,7,8-chlorinated PCDD/Fs & I-TEQ \\
\hline \multirow[t]{8}{*}{ flue gas $\left(\mathrm{ng} \mathrm{m}^{-3}\right.$ and $\mathrm{ng}$ of I-TEQ $\mathrm{m}^{-3}$ ) } & \multirow[t]{4}{*}{ inlet } & $\mathrm{DH}$ & $7.3 \pm 1.8$ & $21.9 \pm 6.8$ & $2.3 \pm 0.56$ \\
\hline & & TS & $4.0 \pm 1.1$ & $4.5 \pm 2.3$ & $0.44 \pm 0.12$ \\
\hline & & SK & $3.2 \pm 1.1$ & $7.2 \pm 2.4$ & $0.32 \pm 0.22$ \\
\hline & & ST & $3.1 \pm 0.71$ & $8.4 \pm 1.7$ & $0.69 \pm 0.14$ \\
\hline & \multirow[t]{4}{*}{ outlet } & $\mathrm{DH}$ & $1.5 \pm 0.10$ & $0.40 \pm 0.11$ & $0.99 \pm 0.53$ \\
\hline & & TS & $0.58 \pm 0.041$ & $0.25 \pm 0.063$ & $0.20 \pm 0.0087$ \\
\hline & & SK & $0.95 \pm 0.069$ & $0.51 \pm 0.11$ & $0.022 \pm 0.0018$ \\
\hline & & ST & $1.2 \pm 0.029$ & $0.73 \pm 0.13$ & $0.062 \pm 0.0045$ \\
\hline \multirow[t]{4}{*}{ gypsum ( $\mathrm{ng} \mathrm{kg}^{-1}$ and $\mathrm{ng}$ of I-TEQ $\mathrm{kg}^{-1}$ ) } & \multicolumn{2}{|c|}{$\mathrm{DH}$} & 1836 & 6589 & 525 \\
\hline & \multicolumn{2}{|c|}{ TS } & 940 & 1200 & 120 \\
\hline & \multicolumn{2}{|c|}{ SK } & 653 & 1900 & 78.7 \\
\hline & \multicolumn{2}{|c|}{ ST } & 394 & 2141 & 106.7 \\
\hline \multirow[t]{10}{*}{ fly ash ( $\mathrm{ng} \mathrm{kg}^{-1}$ and ng of I-TEQ $\mathrm{kg}^{-1}$ ) } & \multirow[t]{4}{*}{$\mathrm{DH}$} & D1 & 3363 & 8353 & 352 \\
\hline & & $\mathrm{D} 2$ & 8670 & 8554 & 369 \\
\hline & & D3 & 38535 & 10772 & 495 \\
\hline & & D4 & 95787 & 14157 & 642 \\
\hline & \multirow[t]{4}{*}{ TS } & $\mathrm{T} 1$ & 2044 & 2932 & 231 \\
\hline & & $\mathrm{T} 2$ & 9709 & 10811 & 662 \\
\hline & & $\mathrm{T} 3$ & 35723 & 14496 & 725 \\
\hline & & $\mathrm{T} 4$ & 52464 & 18425 & 880 \\
\hline & \multicolumn{2}{|c|}{ SK (mixed) } & 46200 & 16380 & 515 \\
\hline & \multicolumn{2}{|c|}{ ST (mixed) } & 34500 & 9652 & 472 \\
\hline
\end{tabular}

The mass spectrometer was operated at a resolution of at least 10000 in selected ion monitoring mode. Two ions among $\mathrm{M}+$, $M+2$, and $M+4$ were monitored. The PCDD/Fs congeners as well as the total for the homologues were identified and quantified on the basis of the retention time and the isotope ratios. The concentrations of the $27 \mathrm{MoCDD} / \mathrm{F}$ to OCDD/F congeners (including 1-MoCDD, 2-MoCDD, 2,3-DiCDD, 2,3,7-TrCDD, 1-MoCDF, 2-MoCDF, 3-MoCDF, 4-MoCDF, 2,8-DiCDF, 2,4,8-TrCDF, and 17 2,3,7,8-chlorinated PCDD/ Fs) in the samples were analyzed. Six less chlorinated PCDD/ Fs (2-MoCDF, 2,8-DiCDF, 2,4,8-TrCDF, 2-MoCDD, 2,3DiCDD, and 2,3,7-TrCDD included in EDF-4955) and 13 2,3,7,8-chlorinated PCDD/Fs (2,3,7,8-TCDF, 2,3,4,7,8PeCDF, 1,2,3,4,7,8-HxCDF, 1,2,3,6,7,8-HxCDF, 2,3,4,6,7,8HxCDF, 1,2,3,4,6,7,8-HpCDF, OCDF, 2,3,7,8-TCDD, 1,2,3,7,8-PeCDD, 1,2,3,4,7,8-HxCDD, 1,2,3,6,7,8-HxCDD, $1,2,3,4,6,7,8-\mathrm{HpCDD}$, and OCDD included in EN-1948 ES) were identified and quantified by corresponding ${ }^{13} \mathrm{C}_{12}$-labeled internal standards. For the congeners without, corresponding ${ }^{13} \mathrm{C}_{12}$-labeled internal standards (including 1-MoCDF, 3MoCDF, 4-MoCDF, 1,2,3,7,8-PeCDF, 1,2,3,7,8,9-HxCDF, 1,2,3,4,7,8,9-HpCDF, 1-MoCDD, and 1,2,3,7,8,9-HxCDD) were identified and quantified by ${ }^{13} \mathrm{C}_{12}$-labeled internal standards of the similar congeners. The levels of the monoto octachlorinated homologues were estimated by the average of ${ }^{13} \mathrm{C}_{12}$-labeled internal standards of the similar congeners. The 2,3,7,8-chlorinated $\mathrm{PCDD} / \mathrm{Fs}$ congener recoveries were 43$126 \%$, while the less chlorinated PCDD/Fs congener recoveries were $42-97 \%$.

\section{RESULTS AND DISCUSSION}

$\mathrm{MoCDD} / \mathrm{F}$ to $\mathrm{OCDD} / \mathrm{F}$ Concentrations in the Flue Gas and Gypsum Samples. The concentrations of the 27 $\mathrm{MoCDD} / \mathrm{F}$ to $\mathrm{OCDD} / \mathrm{F}$ congeners in the flue gas, gypsum, and fly ash samples are listed in Table 1 . The 2,3,7,8chlorinated PCDD/F TEQs were calculated using internationally accepted toxic equivalence factors. ${ }^{23}$
The MoCDD/F to $\mathrm{TrCDD} / \mathrm{F}$ concentrations were $2.1-9.2$ $\mathrm{ng} \mathrm{m}{ }^{-3}$ (mean of $4.4 \pm 2.3 \mathrm{ng} \mathrm{m}^{-3}$ ) in the inlet flue gas samples and $0.38-1.67 \mathrm{ng} \mathrm{m}^{-3}$ (mean of $0.87 \pm 0.48 \mathrm{ng} \mathrm{m}^{-3}$ ) in the outlet flue gas samples, so the removal efficiencies were 69.9$87.2 \%$. The 2,3,7,8-chlorinated PCDD/F concentrations were $2.2-28.7 \mathrm{ng} \mathrm{m}^{-3}$ (mean of $10.5 \pm 8.3 \mathrm{ng} \mathrm{m}^{-3}$ ) in the inlet flue gas samples and $0.29-0.87 \mathrm{ng} \mathrm{m}^{-3}$ (mean of $0.47 \pm 0.22 \mathrm{ng}$ $\mathrm{m}^{-3}$ ) in the outlet flue gas samples, so the removal efficiencies were $91.2-98.2 \%$. The TEQ concentrations were $0.094-2.9 \mathrm{ng}$ of I-TEQ m ${ }^{-3}$ (mean of $0.95 \pm 0.093 \mathrm{ng}$ of I-TEQ $\mathrm{m}^{-3}$ ) in the inlet flue gas samples and $0.012-0.15 \mathrm{ng}$ of I-TEQ $\mathrm{m}^{-3}$ (mean of $0.051 \pm 0.040 \mathrm{ng}$ of I-TEQ $\mathrm{m}^{-3}$ ) in the outlet flue gas samples, so the removal efficiencies were $91.0-95.8 \%$.

The MoCDD/F to TrCDD/F, 2,3,7,8-chlorinated PCDD/F, and TEQ concentrations in the gypsum samples were 3941836, 1200-6589, and 78.7-525 ng of I-TEQ kg-1, respectively. The dioxin mass balance in the desulfurization process was analyzed and is presented in Table S2, among the inlet and outlet flue gas as well as gypsum. The concentrations of $\mathrm{MoCDD} / \mathrm{F}$ to $\mathrm{TrCDD} / \mathrm{F}$ in the gypsum and outlet flue gas accounted for $73.0-88.2 \%$ of those in the inlet flue gas, and the concentrations of $2,3,7,8$-chlorinated $\mathrm{PCDD} / \mathrm{F}$ in the gypsum and outlet flue gas accounted for $77.3-84.5 \%$ of those in the inlet flue gas. The compounds that were thought to be removed from the flue gases were adsorbed by the gypsum, causing the gypsum to be classified as toxic waste. In China, gypsum is treated in three main ways, by being recycled, discarded, or reused (as an important raw material in the construction industry).

To the best of our knowledge, this was the first intensive investigation of $\mathrm{MoCDD} / \mathrm{F}$ to $\mathrm{TrCDD} / \mathrm{F}$ concentrations in flue gases and gypsum samples from sintering plants, and no previously published data on $\mathrm{MoCDD} / \mathrm{F}$ to $\operatorname{TrCDD} / \mathrm{F}$ concentrations in samples collected in sintering plants are available to compare with our concentrations. Our data provide some clues about the pathways through which the PCDD/Fs formed and the mechanisms involved in transformations 

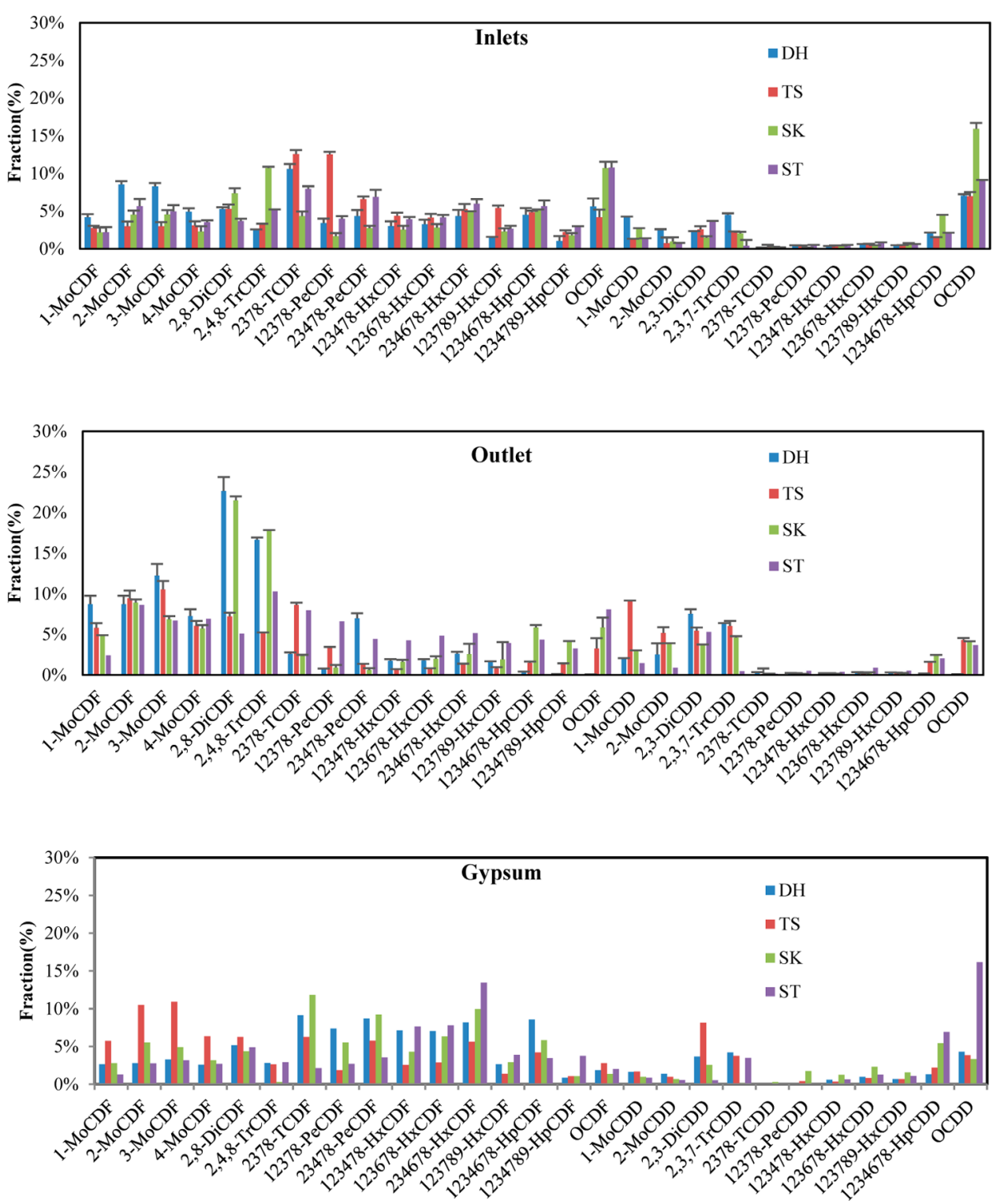

Figure 2. PCDD/F congener profiles in the inlet and outlet flue gas samples and the gypsum samples.

between nontoxic PCDD/F congeners and toxic 2,3,7,8chlorinated $\mathrm{PCDD} / \mathrm{F}$ congeners.

It should be noted that the TEQ concentrations in the inlet gases were higher than the Chinese standard (GB 28662-2012) of $0.5 \mathrm{ng}$ of I-TEQ $\mathrm{m}^{-3}$ and that the desulfurization systems decreased the concentrations to $<0.1 \mathrm{ng}$ of I-TEQ $\mathrm{m}^{-3}$. The desulfurization installations operated at $<200{ }^{\circ} \mathrm{C}$, so the formation of PCDD/Fs during desulfurization was avoided. ${ }^{24}$ The TEQ concentrations were higher in the gypsum samples than those that have been found in soil samples ${ }^{25-27}$ and in fly ash collected in primary magnesium smelting and coking plants. $^{28,29}$ The pollution of PCDD/Fs in gypsum cannot be ignored.

The removal efficiency was calculated using the formula $\mathrm{RE}_{\%}$ $=\left(C_{\mathrm{IN}}-C_{\mathrm{OUT}}\right) / C_{\mathrm{IN}} \times 100 \%$. According to the results presented in this study, the TEQ concentrations after the electrostatic precipitators (i.e., before the desulfurization systems) did not exceed $1.0 \mathrm{ng}$ of I-TEQ $\mathrm{m}^{-3}$ (except in plant DH). Therefore, a further decrease of 91.0-95.8\% achieved using desulfurization systems would guarantee that $\mathrm{PCDD} / \mathrm{F}$ emissions would be lower than $0.5 \mathrm{ng}$ of I-TEQ $\mathrm{m}^{-3}$.
The desulfurization systems were originally designed to decrease $\mathrm{SO}_{2}$ emissions, so the conditions under which the systems were operated were not optimized for eliminating PCDD/Fs. The TEQ removal efficiencies achieved by the desulfurization systems were excellent and were higher than TEQ removal efficiencies that have been found using electrostatic precipitators $(41.4 \%){ }^{24}$ wet fine scrubbers $(68.4 \%){ }^{24}$ and selective catalytic reduction systems (69.0\%). ${ }^{6}$ In addition, the $\mathrm{PCDD} / \mathrm{F}$ homologue removal efficiencies increased as the number of chlorine substituents increased, as shown in Figure S1. This would mainly have been caused by the PCDD/Fs partitioning between the solid and vapor phases. $^{30}$ Generally, less chlorinated PCDD/F homologues have vapor pressures higher than those of more chlorinated homologues, so larger proportions of less chlorinated than more chlorinated PCDD/Fs will be found in the gaseous phase at a specific temperature. More chlorinated homologues are more likely than less chlorinated homologues to condense onto particulate matter. ${ }^{31}$ A desulfurization system will intercept solid particles in sintering flue gas, so a desulfurization system will effectively remove solid-phase $\mathrm{PCDD} / \mathrm{Fs}$ but will be 
ineffective at removing gas-phase PCDD/Fs. The more chlorinated $\mathrm{PCDD} / \mathrm{F}$ congeners will therefore be removed more efficiently than the less chlorinated congeners.

The PCDD/F concentrations in the samples from the different plants varied considerably. The MoCDD/F to $\mathrm{OCDD} / \mathrm{F}$ concentrations were higher in the flue gases emitted from plant $\mathrm{DH}$ than in the flue gases emitted from the other plants. Plant DH had outdated facilities, ${ }^{32}$ and the proportion of recycled material added to raw materials was much higher (>20\%) than at the other plants. This could explain why the $\mathrm{PCDD} / \mathrm{F}$ concentrations were higher at plant $\mathrm{DH}$ than at the

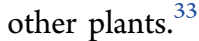

$\mathrm{MoCDD} / \mathrm{F}$ to $\mathrm{OCDD} / \mathrm{F}$ congener profiles in the flue gas and gypsum samples were studied. The $\mathrm{MoCDD} / \mathrm{F}$ to $\mathrm{TrCDD} / \mathrm{F}$ and 2,3,7,8-chlorinated PCDD/F congener profiles found in the inlet and outlet flue gas samples and the gypsum samples are shown in Figure 2. The congener concentrations were normalized to the sum of the 27 congeners to minimize the influence of the concentrations of particular congeners.

The overall PCDD/F congener profiles in the inlet flue gases were similar for all of the sintering plants, indicating that similar $\mathrm{PCDD} / \mathrm{F}$ formation mechanisms occurred in all of the plants and that the characteristics of the emissions were not strongly affected by the operating conditions or the sinter mixture used. The less chlorinated PCDF congeners were found at concentrations higher than those of the less chlorinated PCDD congeners in the inlet flue gases. The dominant congener, 2-MoCDF, contributed $3.0-8.5 \%$ of the total $\mathrm{PCDD} / \mathrm{Fs}$ concentrations, and the next most abundant congeners, 2,4,8-TrCDF and 2,8-DiCDF, contributed 2.510.7 and $3.7-7.4 \%$, respectively. These congeners have also been found to be very dominant in samples collected in waste incineration and organic chemical plants. ${ }^{14,18}$ This was attributed to positions 2, 4, and 8 of the PCDF ring having relatively low bond dissociation energies. ${ }^{17} 2,3-\mathrm{DiCDD}$ and 1MoCDD contributed $1.5-3.6$ and $1.3-4.3 \%$, respectively, of the total PCDD/Fs concentrations. 2,3,7,8-Tetra (T) CDF was the predominant 2,3,7,8-chlorinated PCDF congener, and it contributed $4.4-12.6 \%$ of the total $\mathrm{PCDD} / \mathrm{F}$ concentrations. $2,3,4,7,8-\mathrm{PeCDF}$ was the main contributor to the total TEQs, contributing $37.3-50.8 \%$.

The desulfurization systems achieved excellent removal efficiencies for the $27 \mathrm{PCDD} / \mathrm{F}$ congeners. The removal efficiencies were higher for the more chlorinated PCDD $/ F$ congeners than for the less chlorinated congeners. The contributions of the less chlorinated $\mathrm{PCDD} / \mathrm{F}$ congeners to the total PCDD/F concentrations were generally increased by the desulfurization systems, but the contributions of the 2,3,7,8chlorinated $\mathrm{PCDD} / \mathrm{F}$ congeners were generally decreased. The mean contribution of 2,8-DiCDF (the dominant PCDD/F congener) to the total $\mathrm{PCDD} / \mathrm{F}$ concentrations was increased from 5.1 to $21.7 \%$ by the desulfurization systems. The mean contribution of 2,3,7,8-TCDF (the predominant 2,3,7,8chlorinated $\mathrm{PCDD} / \mathrm{F}$ congener) to the total $\mathrm{PCDD} / \mathrm{F}$ concentrations was decreased from 8.6 to $2.4 \%$ by the desulfurization systems. The mean contribution of 2,3,4,7,8PeCDF (the main contributor to the TEQ) to the total TEQs was also decreased from 43.2 to $38.0 \%$ by the desulfurization systems.

The contributions of the 2,3,7,8-chlorinated PCDD/Fs to the total PCDD/F concentrations (mean of $66.0 \%$ ) were higher than the contributions of the less chlorinated congeners in the gypsum samples. This is evidence that the PCDD/Fs that were removed during the desulfurization process were transferred to the gypsum. 2,3,4,6,7,8-Hexa ( $\mathrm{Hx}$ ) CDF (which contributed a mean of $9.3 \%$ of the total PCDD/F concentrations) was the dominant $\mathrm{PCDD} / \mathrm{F}$ congener. 3-MoCDF (which contributed a mean of $5.6 \%$ of the total PCDD/F concentrations) was the dominant less chlorinated congener.

MoCDD/F to OCDD/F Homologue Distributions in the Flue Gas and Gypsum Samples. The PCDD/F homologue distributions found in the inlet and outlet flue gas samples and the gypsum samples are shown in Figure 3.
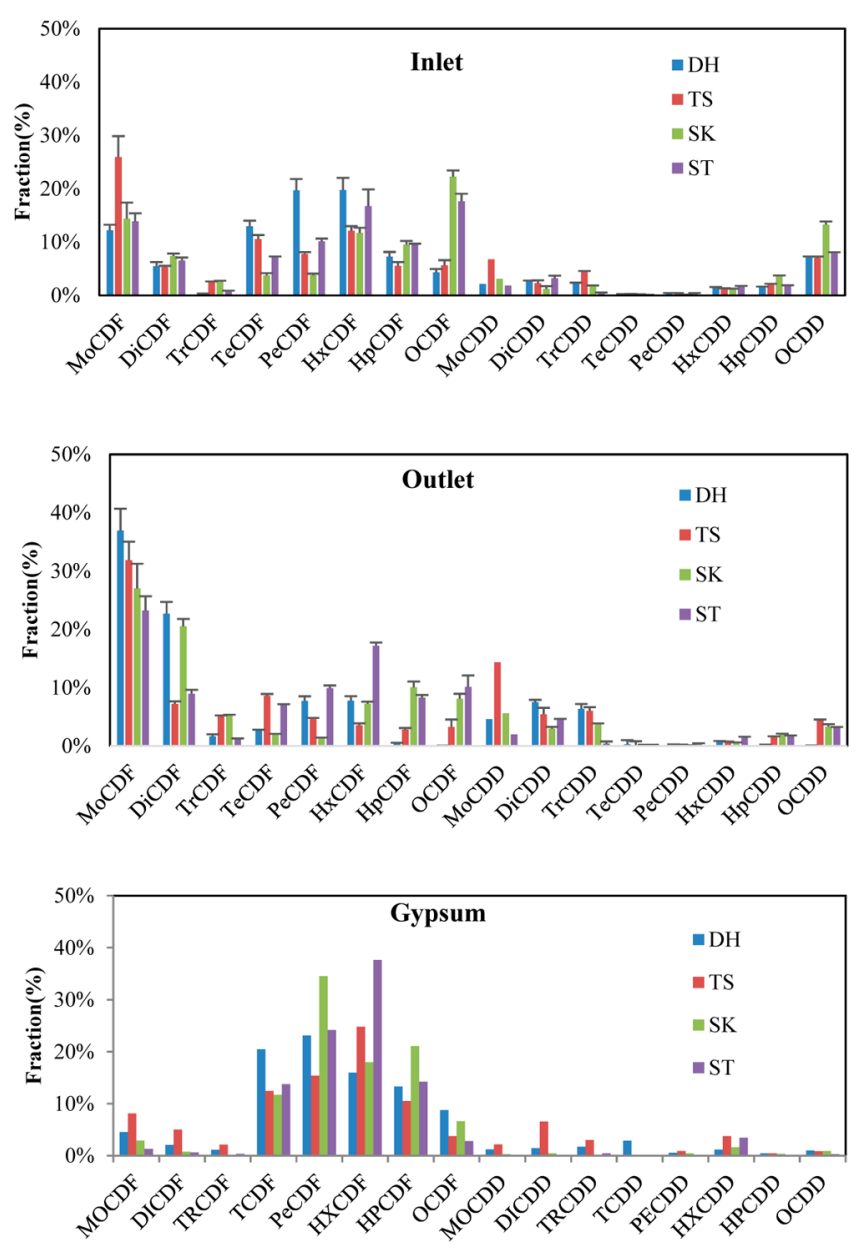

Figure 3. PCDD/F homologue distributions in the inlet and outlet flue gas samples and the gypsum samples.

The MoCDD/F to TrCDD/F homologues were found at concentrations lower than those of the TCDD/F to OCDD/F homologues in the inlet flue gas samples. The MoCDD/F to TrCDD/F homologues contributed $25.1-47.3 \%$ of the total $\mathrm{PCDD} / \mathrm{F}$ concentrations. The contributions of the MoCDD/F to $\mathrm{TrCDD} / \mathrm{F}$ homologue groups to the total $\mathrm{PCDD} / \mathrm{F}$ concentrations decreased as the chlorination level increased, whereas the contributions of the TCDD/F to OCDD/F homologues varied. The homologue patterns were rather different from the patterns that have been found in samples from waste incineration plants. ${ }^{18}$ The MoCDFs (which contributed $12.2-26.0 \%$ of the total PCDD/F concentrations) were the most abundant homologue group in the inlet flue gas samples. The MoCDDs and DiCDFs were also relatively abundant less chlorinated homologues, contributing 5.3-7.4 and $1.9-6.7 \%$, respectively, of the total $\mathrm{PCDD} / \mathrm{F}$ concen- 
trations. The HxCDFs (which contributed $11.7-19.8 \%$ of the total PCDD/F concentrations) were the dominant 2,3,7,8chlorinated homologue group.

The TCDD/F to OCDD/F homologue contributions to the total $\mathrm{PCDD} / \mathrm{F}$ concentrations were smaller and the $\mathrm{MoCDD} / \mathrm{F}$ to $\mathrm{TrCDD} / \mathrm{F}$ homologue contributions larger in the outlet flue gas samples than in the inlet flue gas samples. The MoCDFs were the most abundant $\mathrm{PCDD} / \mathrm{F}$ homologue group in the outlet flue gases, the mean contribution to the total PCDD/F concentrations being $29.8 \%$. The DiCDFs were the next most abundant homologue group, contributing a mean of $14.8 \%$ of the total PCDD/F concentrations. The HxCDFs were the dominant 2,3,7,8-chlorinated PCDD/F homologue group, the mean contribution to the total $\mathrm{PCDD} / \mathrm{F}$ concentrations being $8.9 \%$.

We compared the influences of the wet and semidry desulfurization systems on the MoCDD/F to OCDD/F homologues in the flue gas samples. The MoCDF and DiCDF contributions to the total PCDD/F concentrations were increased by 24.7 and $17.2 \%$, respectively, by the wet desulfurization system and were increased by a further 9.3 and $5.8 \%$, respectively, by the semidry desulfurization systems. The TCDF, PeCDF, and HxCDF contributions were decreased by $10.4,12.0$, and $12.0 \%$, respectively, by the wet desulfurization system and were decreased further by $1.3,1.9$, and $4.2 \%$, respectively, by the semidry desulfurization systems.

The TCDD/F to OCDD/F homologues were found at concentrations much higher than those of the MoCDD/F to $\mathrm{TrCDD} / \mathrm{F}$ homologues in the gypsum samples. The TCDD/F to $\mathrm{OCDD} / \mathrm{F}$ homologues contributed $60.5-83.8 \%$ of the total $\mathrm{PCDD} / \mathrm{F}$ concentrations. These results were in agreement with the desulfurization processes removing the TCDD/Fs to OCDD/Fs from flue gas more efficiently than they removed the MoCDD/Fs to TrCDD/Fs. The PeCDFs dominated the homologue patterns in the gypsum samples, contributing a mean of $24.3 \%$ of the total PCDD/F concentrations. The MoCDFs were relatively abundant and contributed a mean of $4.2 \%$ of the total PCDD/F concentrations.

The total PCDD to total PCDF concentration ratio and the average degree of chlorination (the average number of chlorine atoms in each molecule) have previously been used to "fingerprint" samples. ${ }^{3}$ The total PCDD to total PCDF concentration ratios are listed in Table S3. The ratios for the $\mathrm{MoCDD} / \mathrm{Fs}$ to $\mathrm{TrCDD} / \mathrm{Fs}$ in the inlet and outlet flue gas samples were higher than the ratios for the TCDD/Fs to OCDD/Fs. The PCDD average degrees of chlorination (4.36.2) and the PCDF average degrees of chlorination (3.7-5.1) showed that the PCDD/Fs were more chlorinated in the inlet flue gas samples than in the outlet flue gas samples (for which the PCDD and PCDF average degrees of chlorination were 2.4-4.4 and 2.3-4.2, respectively). This would have been the case because the less chlorinated $\mathrm{PCDD} / \mathrm{Fs}$ made larger contributions to the total $\mathrm{PCDD} / \mathrm{F}$ concentrations after the flue gases had been desulfurized. Considering the congener profiles and homologue distributions from this study and our previous studies and quantum chemical investigation of formation of $\mathrm{PCDD} / \mathrm{Fs},{ }^{14,34}$ we concluded that the less chlorinated $\mathrm{PCDD} / \mathrm{Fs}$ are precursors that are chlorinated to form the 2,3,7,8-chlorinated PCDD/Fs during the sintering process.

MoCDD/F to OCDD/F Emissions and Characteristics in Fly Ash Samples. Fly ash collected in the first, second, and third stages of the electrostatic precipitators in the sintering plants was recycled to allow residual metals in the ash to be recovered. Fly ash collected in the fourth stage of each electrostatic precipitator was discarded and would be classified as waste treated by landfill. The PCDD/F concentrations in the fly ash samples are listed in Table 1 . The concentrations clearly increased from the first to the fourth stages of the electrostatic precipitators in plants $\mathrm{DH}$ and TS. The MoCDD/F to TrCDD/F concentrations in the fly ash samples were 2044$95787 \mathrm{ng} \mathrm{kg}{ }^{-1}$. This is the first intensive investigation of $\mathrm{MoCDD} / \mathrm{F}$ to $\mathrm{TrCDD} / \mathrm{F}$ concentrations in fly ash samples produced in sintering plants, so no MoCDD/F to TrCDD/F concentration data for other sintering plants are available to compare with our data. The 2,3,7,8-chlorinated PCDD/F concentrations were $2638-18425 \mathrm{ng} \mathrm{kg}^{-1}(172-880 \mathrm{ng}$ of ITEQ $\mathrm{kg}^{-1}$ ). These concentrations were higher than those that have been found in fly ash from primary magnesium smelting plants $^{35}$ and coking plants ${ }^{35}$ and similar to concentrations that have been found in municipal solid waste incineration fly ash. ${ }^{21}$ The MoCDD/F to TrCDD/F concentrations in the fly ash samples were almost 2.3 times higher than the 2,3,7,8chlorinated $\mathrm{PCDD} / \mathrm{F}$ concentrations. The MoCDD/F to $\mathrm{TrCDD} / \mathrm{F}$ concentrations increased by $223 \%$, on average, from the first to the fourth stages of the precipitators in plants $\mathrm{DH}$ and TS, whereas the TCDD/F to OCDD/F concentrations and TEQs increased by only 66.4 and $47.7 \%$, respectively.

More fine particles are produced during the sintering process than during the waste incineration process. This would mean that more MoCDD/Fs to TrCDD/Fs would be adsorbed in sintering plants than in waste incinerators when the flue gases are passed through an electrostatic precipitator. The proportions of the MoCDD/Fs to TrCDD/Fs found in the flue gases were not much higher in our samples than those that have been found in waste incineration flue gases.

The particle size clearly decreased and the BrunauerEmmett-Teller surface areas increased moving from the first to the fourth stages of the precipitators in plants $\mathrm{DH}$ and TS (Table S4). This shows that the finer fly ash had a larger specific surface area, which would favor the adsorption of $\mathrm{PCDD} / \mathrm{Fs}$. The MoCDD/Fs to $\mathrm{TrCDD} / \mathrm{Fs}$ have vapor pressures higher than those of the 2,3,7,8-chlorinated PCDD/ Fs and larger proportions of the MoCDD/Fs to TrCDD/Fs than 2,3,7,8-chlorinated PCDD/Fs will therefore be in the gaseous phase. The MoCDD/Fs to TrCDD/Fs will therefore more easily adsorb onto finer particles than will the 2,3,7,8chlorinated PCDD/Fs because of the high surface area/volume ratios of the fine particles. The PCDD/F homologue distributions in the fly ash samples, shown in Figure S2, indicated that the fraction of the MoCDD/Fs to TrCDD/Fs present in the fly ash increased moving along the electrostatic precipitators.

Emission Inventory of MoCDD/Fs to OCDD/Fs in China from 2003 to 2012. The emission factor of a contaminant is typically used to estimate the total amount of that contaminant that is emitted each year, to establish an inventory. The MoCDD/F to $\operatorname{TrCDD} / \mathrm{F}$ emission factors for the inlet and outlet flue gases and gypsum were 17.6, 4.2, and $10.6 \mu \mathrm{g} \mathrm{t}^{-1}$, respectively. The TEQ emission factors for the gypsum were very different for different sized sintering plants $\left(<90\right.$ and $\left.>90 \mathrm{~m}^{2}\right)$. Therefore, we divided the emission factors into two classes to allow the emissions to be estimated accurately. The emission factor for $<90 \mathrm{~m}^{2}$ sintering plants was $5.9 \mu \mathrm{g}$ of I-TEQ $\mathrm{t}^{-1}$, and the emission factor for $>90 \mathrm{~m}^{2}$ 
sintering plants was $1.1 \mu \mathrm{g}$ of I-TEQ $\mathrm{t}^{-1}$. The TEQ emission factors for the inlet and outlet flue gases were 3.3 and $0.18 \mu \mathrm{g}$ of I-TEQ $\mathrm{t}^{-1}$, respectively.

We combined the sintering outputs (shown in Figure S3) and the percentage of plants that had desulfurization systems (shown in Figure 4) between 2003 and 2012. The total $\mathrm{MoCDD} / \mathrm{F}$ to $\mathrm{TrDD} / \mathrm{F}$ emissions were preliminarily estimated to be $\sim 10.7 \mathrm{~kg}$ in flue gas and $10.2 \mathrm{~kg}$ in gypsum from 2003 to 2012.

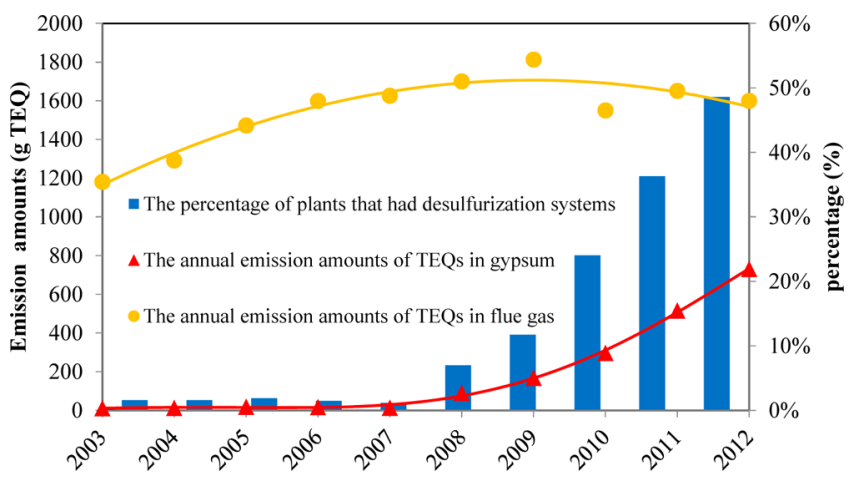

Figure 4. Annual I-TEQ emissions in flue gases and gypsum from sintering plants in China and the percentage of plants with desulfurization systems between 2003 and 2012 .

The annual TEQ emissions released in flue gas and gypsum by the sintering industry from 2003 to 2012 were estimated, and the results are shown in Figure 4. Annual TEQ emissions to the atmosphere from Chinese sintering plants gradually decreased as the percentage of plants with desulfurization systems increased. In contrast, TEQ emissions in gypsum increased. The total TEQ emitted in gypsum between 2003 and 2012 was found to be $1878 \mathrm{~g}$ of I-TEQ, which accounted for $12.1 \%$ of the total PCDD/F TEQs emitted to the atmosphere (15486 $\mathrm{g}$ of I-TEQ). It is noteworthy that PCDD/Fs in gypsum are not effectively eliminated and will probably reenter the environment and become a new source of PCDD/Fs. Therefore, the risks posed by $\mathrm{PCDD} / \mathrm{Fs}$ in gypsum are important and should be managed more effectively than they are currently. We speculate that desulfurization might play a key role in controlling PCDD/F emissions. All sintering plants will have to be fitted with desulfurization systems by the end of 2015 to meet Chinese legislation, and we estimate that only $735 \mathrm{~g}$ of PCDD/Fs will be emitted annually by Chinese sintering plants from that time.

It is important to identify key regions in which sintering plants emit PCDD/Fs, and this is an essential primary step when developing and implementing emission controls. The spatial distributions of $\mathrm{PCDD} / \mathrm{Fs}$ emitted by the Chinese sintering industry in 2003 and 2012 are shown in Figure 5. Five provinces in North China (Hebei, Shanxi, Tianjin, Inner Mongolia, and Beijing) are the main areas in which PCDD/Fs are emitted by the sintering industry. PCDD/F emissions in this region accounted for $40.0 \%$ of all industrial emissions of PCDD/Fs in 2003, but this had decreased to $35.9 \%$ in 2012. The decrease may have been caused by the percentage of plants with desulfurization systems increasing to $47.9 \%$ by 2012 . The same region also suffers from serious air pollution that causes toxic effects. It is possible that these pollutants may exist in symbiotic relationships, which will be a reference for future research into synergistic decreases in emissions. Sintering flue gas contains not only PCDD/Fs but also brominated dibenzo$p$-dioxins and dibenzofurans, halogenated polycyclic aromatic hydrocarbons, polychlorinated biphenyls, and polychlorinated naphthalenes. Using desulfurization systems could lead to synergistic decreases in emissions of these unintentionally produced persistent organic pollutants (UP-POPs) that have properties similar to those of PCDD/Fs. Moreover, appropriate emphasis should be placed on controlling UP-POPs in gypsum as these compounds are not effectively eliminated.

\section{ASSOCIATED CONTENT}

\section{Supporting Information}

The Supporting Information is available free of charge on the ACS Publications website at DOI: 10.1021/acs.est.5b06095.

Operational information about sintering plants (Table S1), PCDD/F mass balances (Table S2), total PCDD to total PCDF concentration ratios and average degrees of chlorination in flue gas samples (Table S3), particle sizes and Brunauer-Emmett-Teller surface areas of fly ashes from the first to the fourth stages of the precipitators in plants $\mathrm{DH}$ and TS (particle size = mean volume) (Table S4), removal efficiencies of $\mathrm{PCDD} / \mathrm{Fs}$ homologues (Figure S1), PCDD/F homologue distributions in the
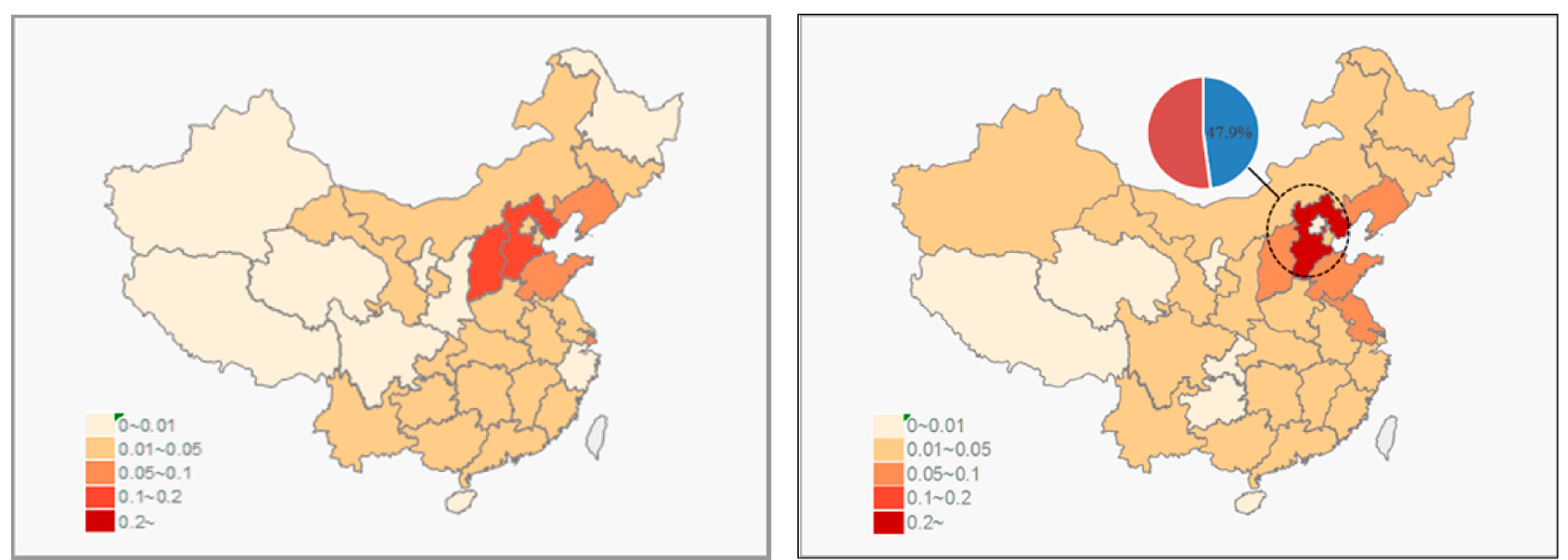

Figure 5. Spatial distributions of PCDD/F emissions (kilograms of I-TEQ) from sintering plants in 2003 (left) and 2012 (right). The percentage of plants with desulfurization systems in the region of interest in 2012 is shown in the pie chart. 
fly ash samples (Figure S2), and annual production of sintering ore in China (Figure S3) (PDF)

\section{AUTHOR INFORMATION}

\section{Corresponding Author}

*Telephone: +86-10-62849356. Fax: +86-10-62849172. E-mail: liuwb@rcees.ac.cn.

\section{Notes}

The authors declare no competing financial interest.

\section{ACKNOWLEDGMENTS}

This study was supported by the National 973 Program (2015CB453103), the Strategic Priority Research Program of the Chinese Academy of Sciences (XDB14020000), and the National Natural Science Foundation of China (21477150, 21321004, and 41171250).

\section{REFERENCES}

(1) Colombo, A.; Benfenati, E.; Mariani, G.; Lodi, M.; Marras, R.; Rotella, G.; Senese, V.; Fattore, E.; Fanelli, R. PCDD/Fs in ambient air in north-east Italy: the role of a MSWI inside an industrial area. Chemosphere 2009, 77 (9), 1224-1229.

(2) Li, S.; Zheng, M.; Liu, W.; Liu, G.; Xiao, K.; Li, C. Estimation and characterization of unintentionally produced persistent organic pollutant emission from converter steelmaking processes. Environ. Sci. Pollut. Res. 2014, 21 (12), 7361-7368.

(3) Liu, G.; Zheng, M.; Liu, W.; Wang, C.; Zhang, B.; Gao, L.; Su, G.; Xiao, K.; Lv, P. Atmospheric Emission of PCDD/Fs, PCBs, Hexachlorobenzene, and Pentachlorobenzene from the Coking Industry. Environ. Sci. Technol. 2009, 43 (24), 9196-9201.

(4) Lv, P.; Zheng, M.; Liu, W.; Zhang, B.; Liu, G.; Su, G.; Nie, Z. Estimation of Emissions of Polychlorinated Dibenzo-p-Dioxins and Dibenzofurans and Dioxin-Like Polychlorinated Biphenyls from Chinese Hot Dip Galvanizing Industries. Environ. Eng. Sci. 2011, 28 (9), 671-676.

(5) Everaert, K.; Baeyens, J. The formation and emission of dioxins in large scale thermal processes. Chemosphere 2002, 46 (3), 439-448.

(6) Wang, L.; Lee, W.; Tsai, P.; Lee, W.; Chang-Chien, G. Emissions of polychlorinated dibenzo-p-dioxins and dibenzofurans from stack flue gases of sinter plants. Chemosphere 2003, 50 (9), 1123-1129.

(7) Chen, Y.; Tsai, P.; Mou, J. Determining optimal operation parameters for reducing PCDD/F emissions (I-TEQ values) from the iron ore sintering process by using the Taguchi experimental design. Environ. Sci. Technol. 2008, 42 (14), 5298-5303.

(8) Ooi, T.; Aries, E.; Anderson, D.; Fray, R.; Thompson, D. Melamine as suppressant of $\mathrm{PCDD} / \mathrm{F}$ formation in the sintering process. Organohalogen Compd. 2008, 70, 58-61.

(9) Boscolo, M.; Padoano, E. Investigations into dioxin emissions at Italian iron ore sintering plant. Ironmaking Steelmaking 2008, 35 (5), $338-342$.

(10) Anderson, D. R; Fisher, R. Sources of dioxins in the United Kingdom: the steel industry and other sources. Chemosphere 2002, 46 (3), 371-381.

(11) Ooi, T. C.; Lu, L. Formation and mitigation of PCDD/Fs in iron ore sintering. Chemosphere 2011, 85 (3), 291-299.

(12) Buekens, A.; Cornelis, E.; Huang, H.; Dewettinck, T. Fingerprints of dioxin from thermal industrial processes. Chemosphere 2000, 40 (9), 1021-1024.

(13) Fisher, R.; Fray, T. Investigation of the formation of dioxins in the sintering process. 2nd International Congress on the Science and Technology of Ironmaking and 57th Ironmaking Conference; 1998; pp 1183-1193.

(14) Han, Y.; Liu, W.; Pan, W.; Wang, P.; Tian, Z.; Zhao, Y.; Wang, M.; Chen, X.; Liao, X.; Zheng, M. Formation Pathways of Mono-to Octa-Chlorinated Dibenzo-p-dioxins and Dibenzofurans in Main
Organochemical Industries. Environ. Sci. Technol. 2015, 49 (18), 10945-10950.

(15) Hung, P.; Chang, S.; Lin, S.; Buekens, A.; Chang, M. Pilot tests on the catalytic filtration of dioxins. Environ. Sci. Technol. 2014, 48 (7), 3995-4001.

(16) Park, H.; Kim, J.; Chang, Y. Prevalence of low chlorinated dibenzo-p-dioxin/dibenzofurans in human serum. Chemosphere 2013, 90 (5), 1658-1663.

(17) Usami, M.; Sakemi, K.; Tabata, H.; Kawashima, K.; Takanaka, A. Developmental toxicity of 2-chlorodibenzofuran in cultured postimplantation rat embryos. Toxicol. In Vitro 1993, 7 (3), 259-264.

(18) Liu, W.; Tian, Z.; Li, H.; Xie, H.; Xiao, K.; Li, C.; Tang, C.; Zheng, M. Mono- to Octa-chlorinated PCDD/Fs in stack gas from typical waste incinerators and their implications on emission. Environ. Sci. Technol. 2013, 47 (17), 9774-9780.

(19) Gostomczyk, M.; Kordylewski, W. Simultaneous $\mathrm{NO}_{x}$ and $\mathrm{SO}_{2}$ removal in wet and semi-dry FGD. Arch. Combust. 2010, 30 (1-2), $15-24$.

(20) Hu, J.; Zheng, M.; Liu, W.; Li, C.; Nie, Z.; Liu, G.; Xiao, K.; Dong, S. Occupational exposure to polychlorinated dibenzo-p-dioxins and dibenzofurans, dioxin-like polychlorinated biphenyls, and polychlorinated naphthalenes in workplaces of secondary nonferrous metallurgical facilities in China. Environ. Sci. Technol. 2013, 47 (14), 7773-7779.

(21) Liu, G.; Jiang, X.; Wang, M.; Dong, S.; Zheng, M. Comparison of $\mathrm{PCDD} / \mathrm{F}$ levels and profiles in fly ash samples from multiple industrial thermal sources. Chemosphere 2015, 133, 68-74.

(22) Ba, T.; Zheng, M.; Zhang, B.; Liu, W.; Xiao, K.; Zhang, L. Estimation and characterization of $\mathrm{PCDD} / \mathrm{Fs}$ and dioxin-like PCBs from secondary copper and aluminum metallurgies in China. Chemosphere 2009, 75 (9), 1173-1178.

(23) Wang, L.; Hsi, H.; Wang, Y.; Lin, S.; Chang-Chien, G. Distribution of polybrominated diphenyl ethers (PBDEs) and polybrominated dibenzo-p-dioxins and dibenzofurans ( $\mathrm{PBDD} / \mathrm{Fs})$ in municipal solid waste incinerators. Environ. Pollut. 2010, 158 (5), $1595-1602$.

(24) Guerriero, E.; Guarnieri, A.; Mosca, S.; Rossetti, G.; Rotatori, M. $\mathrm{PCDD} / \mathrm{Fs}$ removal efficiency by electrostatic precipitator and wetfine scrubber in an iron ore sintering plant. J. Hazard. Mater. 2009, 172 (2), 1498-1504.

(25) Tian, Z.; Li, H.; Xie, H.; Tang, C.; Han, Y.; Wang, M.; Liu, W. Polychlorinated dibenzo-p-dioxins and dibenzofurans and polychlorinated biphenyls in surface soil from the Tibetan Plateau. J. Environ. Sci. 2014, 26 (10), 2041-2047.

(26) Xu, P.; Tao, B.; Li, N.; Qi, L.; Ren, Y.; Zhou, Z.; Zhang, L.; Liu, A.; Huang, Y. Levels, profiles and source identification of PCDD/Fs in farmland soils of Guiyu, China. Chemosphere 2013, 91 (6), 824-831.

(27) Liu, W.; Li, H.; Tian, Z.; Xie, H.; Hu, J. Spatial distribution of polychlorinated biphenyls in soil around a municipal solid waste incinerator. J. Environ. Sci. 2013, 25 (8), 1636-1642.

(28) Nie, Z.; Liu, G.; Liu, W.; Zhang, B.; Zheng, M. Characterization and quantification of unintentional POP emissions from primary and secondary copper metallurgical processes in China. Atmos. Environ. 2012, 57, 109-115.

(29) Liu, G.; Liu, W.; Cai, Z.; Zheng, M. Concentrations, profiles, and emission factors of unintentionally produced persistent organic pollutants in fly ash from coking processes. J. Hazard. Mater. 2013, 261, 421-426.

(30) Smolka, A.; Schmidt, K. Gas/particle partitioning before and after flue gas purification by an activated-carbon-filter. Chemosphere 1997, 34 (5), 1075-1082.

(31) Kaupp, H.; McLachlan, M. S. Gas/particle partitioning of PCDD/Fs, PCBs, PCNs and PAHs. Chemosphere 1999, 38 (14), $3411-3421$.

(32) Geng, J.; Lu, Y.; Wang, T.; Giesy, J. P.; Chen, C. Effects of energy conservation in major energy-intensive industrial sectors on emissions of polychlorinated dibenzo-p-dioxins and polychlorinated dibenzofurans in China. Energy Policy 2010, 38 (5), 2346-2356. 
(33) Xhrouet, C.; De Pauw, E. Formation of PCDD/Fs in the sintering process: influence of the raw materials. Environ. Sci. Technol. 2004, 38 (15), 4222-4226.

(34) Altarawneh, M.; Dlugogorski, B. Z.; Kennedy, E. M.; Mackie, J. C. Quantum chemical investigation of formation of polychlorodibenzo-p-dioxins and dibenzofurans from oxidation and pyrolysis of 2chlorophenol. J. Phys. Chem. A 2007, 111 (13), 2563-2573.

(35) Nie, Z.; Zheng, M.; Liu, W.; Zhang, B.; Liu, G.; Su, G.; Lv, P.; Xiao, K. Estimation and characterization of $\mathrm{PCDD} / \mathrm{Fs}$, dl-PCBs, PCNs, $\mathrm{HxCBz}$ and $\mathrm{PeCBz}$ emissions from magnesium metallurgy facilities in China. Chemosphere 2011, 85 (11), 1707-1712. 